\title{
An exploration of how spiritual nursing care is applied in clinical nursing practice
}

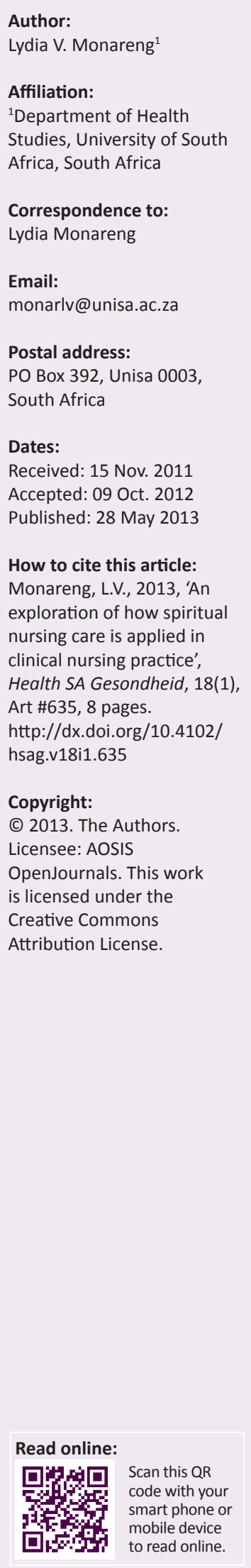

Spiritual nursing care is a significant concept for nurses as they are expected to provide holistic care to patients. Many nurses have difficulty to understand and integrate it into practice and consequently neglect this aspect of care. The study was conducted to explore and describe how professional nurses provide spiritual care to patients. A generic qualitative, explorative and descriptive study was conducted based on Symbolic Interactionism as the philosophical base. The population comprised professional nurses from a public hospital. Participants were recruited through purposive and snowball sampling methods. Data were collected through the use of individual, focus group interviews and observation. Data analysis methods utilised included the NUD*IST computer program, coding, constant comparison method and Tesch's guidelines on data analysis. Findings revealed that nurses struggled to conceptualise spiritual nursing care and to differentiate it from emotional, social or psychological care. However, prayer with or for patients and singing spiritual songs had the highest count of interventions perceived to be effective. Recommendations suggest that the scope of practice and curriculum of training of nurses be reviewed to consider how spiritual nursing care can be evidenced and realised both in the classroom and in the clinical setting. Spiritual nursing care is still a neglected and seemingly complex component of patient care. However, the scientific worldview practices, beliefs and insufficient statutory endorsement of such care hamper its realisation in practice.

Geestelike verpleegsorg is 'n belangrike konsep omdat van verpleegkundiges verwag word om pasiënte holisties te versorg. Baie verpleegkundiges vind dié begrip en die integrering daarvan problematies en verwaardeloos gevolglik hierdie aspek van sorg. Die studie ondersoek en beskryf die mate waartoe verpleegkundiges geestelike sorg aan pasiënte verleen. ' $n$ Basiese kwalitatiewe, ekploratiewe, beskrywende studie is uitgevoer met Simboliese Interaksionisme as die filosofiese basis. Professionele verpleegkundiges in ' $n$ openbare hospitaal is vir die studie gebruik. Deelnemers is deur doelgerigte sneeubal-selekteringsmetodes gewerf. Data is deur individuele-, fokusgroeponderhoude en waarneming ingesamel. Metodes vir dataanalise het die NUD*IST-rekenaarprogram, kodering, konstante vergelykingsmetode en Tesch se riglyne vir data-analise ingesluit. Resultate toon verpleegkundiges vind dit moeilik om geestelike verpleegsorg te konseptualiseer en van emosionele, sosiale of sielkundige sorg te onderskei. Nietemin het gebed met of vir pasiënte en die sing van geestelike liedere die hoogste telling wat as effektiewe intervensie beskou kan word. Aanbevelings suggereer die hersiening van die bestek van praktyk asook die kurrikulum vir die opleiding van verpleegkundiges ten einde sorg te dra dat geestelike verpleegsorg in die klaskamer sowel as in die kliniese praktyk sigbaar en verwesenlik word. Geestelike verpleegsorg is steeds ' $n$ verwaarloosde en oënskynlik 'n komplekse komponent van pasiëntsorg. Desondanks word die praktykverwesenliking daarvan belemmer deur die wetenskaplike wêreldbeskouing, oortuigings en onvoldoende statutêre onderskrywing.

\section{Introduction}

\section{Background information}

Historically, the notion of approaching individuals as bio-psychosocial and spiritual beings has been recognised within the nursing profession. Twenty-six nursing theories were examined by Taylor (2002:38-39) to determine whether nurse theorists actually acknowledge the spiritual domain in their conceptual frameworks. The investigation revealed that 12 of the 26 theories appear to acknowledge the impact of spiritual nursing care on the quality of patient care delivered within the dynamics of holistic nursing care. There is literary evidence that historically, nurses incorporated 'attention to the soul' which implied caring for the spiritual dimension as part of their clinical practice (Taylor 2002:38). Clinical nursing practice refers to actual observation and treatment of sick, ill or injured persons as distinguished from theoretical or experimental observations (Taylor 2002:88). 
In order to meet the needs of patients holistically and to assist them in making sense of their circumstances, spiritual nursing care should be considered equally important as physical, emotional and social care dimensions. Therefore, the concept of holistic nursing care requires that nurses should understand the interconnectedness of the physical, psychological, emotional, social, cultural and spiritual realms and treat their patients accordingly (Freshwater \& Maslin-Prothero 2005:278; Govier 2000:32; Meyer 2003:185). Nurses who appreciate this interconnectedness are likely to ensure that the spiritual component is evident in their patient care practices (Callister et al. 2004:160).

Spiritual nursing care entails activities that facilitate a healthy balance between the bio-psychosocial and spiritual aspects of the person, thus promoting a sense of wholeness and well-being (Taylor 2002:180).

According to McEwen (2005:162), varied themes of spiritual nursing care in the literature represent a variety of worldviews and the opinions of people from diverse backgrounds. Smith and McSherry (2004:308) posit that the human spirit unifies the whole person and potentially promotes health in a very real sense, by ensuring inner harmony or 'shalom', a feeling of peace caused by God-centered human wholeness. The descriptions of spiritual nursing care in the literature range from general conceptions of a caring presence to religiously orientated interventions such as prayer or reading religious texts in relation to God's intervention and his healing powers (Sawatzky \& Pesut 2005:24).

Currently, there is a renewed emphasis on spiritual nursing care with a growing awareness in the literature about issues related to its contribution to quality of patient care and attainment of holistic patient care (Tjale \& Bruce 2007:70). Spiritual nursing care is closely associated with terminal illnesses, however, as humans are spiritual beings, they all have spiritual needs. Hermann (2007:71) ads that spiritual nursing care is related to maintance of hope in patients and helping them find meaning and purpose in their pain. Koslander and Arvidsson (2007:598) view spiritual nursing care as recognition of patient's dignity and showing them love and acceptance in order to assist them to attain emotional wellbeing and inner peace. Although spiritual nursing care seems not to fit well with the understanding of science and what constitutes scientific truth, Awara and Fasey (2008:185) argue that spiritual care brings to clinical practice spiritual gains that result in full or partial transformation of the individual, serving to promote hope and regeneration of faith in patients and caregivers alike. The study was undertaken to explore how spiritual nursing care is provided by professional nurses in the health care context. Professional nurses refer to a nurse registered with the South African Nursing Council (SANC) under section 31(1) of the Nursing Act (The South African Nursing Council [SANC] 2005:34) who provide care to patients in a health care context which involves observing, diagnosing, treating, evaluating, counselling and serving as an advocate for the patient (Freshwater \& Maslin-Prothero 2005:401). An operational definition of spiritual nursing care based on the study findings was that it is care that is humane, which places a high premium on the life of a human being as a whole, with emphasis on caring for the spiritual dimension needs as equally significant as that of body and mind; characterised by availability of the nurse, showing caring presence, mutual respect, compassion, concern and shared responsibility'. However, this definition still needs to be further researched for application in clinical practice, particularly in a multi-religious health care arena.

\section{Problem statement}

The renewed emphasis on spiritual nursing care as an inherent facet of holistic nursing care presents nurses with a significant challenge to understand what this care entails. This understanding is necessary in the light of the confusion about the meaning of the concepts 'spirituality' and 'spiritual nursing care' and the practical implications specifically of the latter concept in clinical nursing practice. McEwen (2005:161) contends that if the nurse educators and researchers do not attempt to make the existence and importance of spiritual nursing care explicit in the domain of holistic nursing care, the nurse practitioner who is directly involved in the delivery of patient care, will not do so either.

It is a noted fact that technological and scientific advances in medicine have increased the quality and effectiveness of health care. However, the focus on science and technology has increasingly overshadowed the concerns for spiritual and humanitarian needs, and this increases the risk of depersonalising ill individuals. With the numerous advances in scientific and medical technology, nursing has become more complex and sometimes even mechanistic. As a result, the relevance of spiritual nursing care tends to be compromised and lost (Sawatzky \& Pesut 2005:21).

Although theoretical and empirical literature addressing spiritual care as it relates to nursing practice is increasing and emerges as an important body of knowledge, spiritual nursing care is still not well understood, nor applied meaningfully in practice. It seemed therefore, necessary to obtain a contextualised view of spiritual nursing care by drawing upon the views of those persons who render such care in the clinical context. The findings on what spiritual nursing care is and is not by differentiating between emotional, psychological care versus spiritual nursing care would enhance understanding holistic patient care. The findings could also serve as a framework for incorporating spiritual nursing care in the curriculum as well as in-service education programmes not only for nurses, but for other health professionals as well for quality patient care. The findings could also have far reaching impact on policy makers and important accreditation bodies such as the SANC, World Health Organisation (WHO) and the Department of Health and Education on the training and education of nurses and adoption of clinical protocols that evidences provision of spiritual nursing care to improve the quality of patient care.

The central theoretical question which guided this study was:

'Tell me, what do you understand by spiritual nursing care and how do you provide such care for your patients?' 


\section{Aim of the study}

The aim of the study was to explore and describe professional nurses' conceptualisation and their experiences of rendering spiritual nursing care.

\section{Research objective}

The objective of the study was to explore and describe how professional nurses conceptualise spiritual nursing care and render such care to their patients.

\section{Research design and method Design}

This study used a qualitative research design to explore and describe professional nurses' conceptualisation of spiritual nursing care. Symbolic interactionism (SI) was used as a philosophical base that guided data collection and analysis. SI is seen as a perspective in empirical social science designed to yield verifiable knowledge of the human group life, conduct or act (Blumer 1969:21). SI, according to Burnier (2005:502), provides the essentials for a provocative philosophical scheme that is attuned to people's social experiences with objects and meanings attached to them in varying contexts.

The meaning of objects lies in the actions that human beings undertake with or toward or against the objects such as words of hope given by nurses to patients (Burnier 2005:502).

\section{Context, population and sample}

The research setting was an 800 bedded academic public hospital. It included a variety of units where both acute and chronically ill patients were cared for. Interviews are merely an extended and formalised conversation with a purpose. Conversations are verbal interactions between two or more individuals who ideally have an equal opportunity to express their viewpoints (Holloway 2005:152; StreubertSpeziale \& Carpenter 2003:28). Limb (2004:64-65) explains that the best way of finding out how people think, feel or behave is by simply asking them about it. Purposive, snowball or network and theoretical sampling techniques were employed to select members who had knowledge and insight on issues of spiritual nursing care. The selection of the 4 participants depended on the researcher's knowledge about the population and what information was needed to answer the research question and objective (Burns \& Grove 2007:344-345; Polit \& Beck 2008:355). Three participants were residing in Black townships and one in a predominantly White suburban area. Although the environment was noisy in the townships, the interviews were conducted in their living rooms which were convenient for seating and taping arrangements. Purposive and snowball sampling process was guided by data saturation where inclusion of individual participants or focus groups terminated when there was no new information sourced in the interviews or discussions conducted.

The biographical data revealed that a homogenous group of $28(100 \%)$ female professional nurses were interviewed of whom four $(14.3 \%)$ were involved in the individual and $24(85.7 \%)$ in the focus group interviews. Of the participants $18(64.3 \%)$ were in the $41-50$ age which resembled stability, maturity and experience. Fifteen of them were married and 13 (46.4\%) single. Of all the participants, only eight (28.6\%) had degrees and $20(71.4 \%)$ had various diplomas and certificates in the field of nursing education and training. However, only five $(17.6 \%)$ of them had training or courses that were related to spirituality and were done in their local churches. They were all from Protestant religious backgrounds that ascribed to the Christian faith.

\section{Data collection methods}

Data collection methods utilised were the unstructured in-depth individual interviews, focus group interviews, direct observation and field notes. Individual interviews were conducted in September 2008 in the homes of four participants. The unstructured interview comprised of one grand tour question which was derived from the central theoretical research question as:

'What do you understand by spiritual nursing care and how do you provide such care for your patients?'

Specific concepts emerged from the unstructured interviews during probing which also guided the semi-structured focus group interviews. An interview guide was used to give direction to data collection, as suggested by Holloway (2005:151-152). It comprised section A for demographic data, section B for the grand tour question and section $C$ was a list of pre determined questions for focus group interviews as follows:

- What do you understand by spiritual nursing care?

- How do you provide spiritual nursing care for your patients?

- How do your religious values guide your care for patients as a nurse?

- What do you understand by holistic patient care?

- What difficulties or barriers do you experience when providing spiritual nursing care?

- How do you handle the identified difficulties or barriers?

All interviews were audio-taped with the permission from the interviewees and transcribed verbatim. Data generated comprised of 54 A4 typed pages with coding data collection focused on gathering data that generated, delimited and saturated concepts that were related to spiritual nursing care. Field notes were kept during and after the interviews. These notes were both descriptive and reflective and complemented the tape recordings done during interviews and data analysis (De Vos 2005:298).

\section{Data analysis}

The qualitative data were analysed using the thematic analysis structure as a framework to interpret data.

Data analysis was ongoing during the data collecting session. The transcriptions were typed and then imported into the code based theory builder which is the Qualitative Research Solutions Non-numerical Unstructured Data ways 
of Indexing, Searching and Theorising computer software, known as NUD*IST after data were broken into distinct text units. Data were categorised with the assistance of the computer into themes, categories and sub-categories. The direct quotes of participants were coded and arranged into text units for analysis. A constant comparison method of data analysis with memo writing was applied. The researcher, for data analysis triangulation purposes engaged in a systematic data analysis process suggested by Creswell (2003:190-195) and integrated it with Tesch's eight steps of analysis to analyse the textual data until themes, categories and subcategories were identified and developed. Variations were noted on the identified subcategories from the computer, but the themes and categories were in most cases similar. A process of open, axial and selective coding was followed as illustrated in Figure 1.

From the data collected, a total of four themes, eight categories and 27 sub-categories were identified as exhibited on Table 1.

\section{Discussion of results}

The following discussions present the analysis and interpretation of the identified themes, categories and sub categories based on the SI philosophy, and where relevant validation with literature. The themes were examined in view of literature with the intent to describe the conceptualisation of nurses about what spiritual nursing care means and how it was provided to patients.

Responses from participants to the questions enabled the analyst to relate what constitutes spiritual nursing care from their perspective and challenges experienced as they provided such care. The ensuing discussions were based on the identified themes, categories and subcategories.

\section{Theme 1: Meaning of spiritual nursing care}

This theme explored and described the meaning of spiritual nursing care in relation to the application of the concept 'spiritual being' as it applies to the nurse and to the patient.
From this theme, the understanding of the interrelationship of body, mind and spirit was explored from the responses presented. Some of the participants referred to their patients as human beings with a spiritual image as exemplified in this excerpt:

'... so this is what challenges me on daily basis that I may treat people well as human beings and as people who are created in the image of God, not a an object which will help me get some money come month end.' (Hellen Sebolai, 53 year old female, professional nurse in HIV / Aids clinic)

TABLE 1: A summary of the themes, categories and subcategories.

\begin{tabular}{|c|c|c|}
\hline Theme & Category & Subcategory \\
\hline \multirow{8}{*}{$\begin{array}{l}\text { Theme 1: } \\
\text { Meaning of spiritual } \\
\text { nursing care }\end{array}$} & \multirow[t]{2}{*}{ Human being } & Nurse \\
\hline & & Patient \\
\hline & \multirow{3}{*}{$\begin{array}{l}\text { Interrelationship of body mind } \\
\text { and spirit }\end{array}$} & Body \\
\hline & & Mind \\
\hline & & Spirit \\
\hline & \multirow{3}{*}{$\begin{array}{l}\text { Challenges of understanding the } \\
\text { meaning of spiritual nursing care }\end{array}$} & Religious care \\
\hline & & Intuitive care \\
\hline & & $\begin{array}{l}\text { Emotional versus } \\
\text { spiritual nursing care }\end{array}$ \\
\hline \multirow{3}{*}{$\begin{array}{l}\text { Theme 2: } \\
\text { Nurse relationships in } \\
\text { the health care arena }\end{array}$} & \multirow[t]{3}{*}{ Relationships } & Nurse-patient \\
\hline & & Nurse-family \\
\hline & & Nurse-colleague \\
\hline \multirow{11}{*}{$\begin{array}{l}\text { Theme 3: } \\
\text { How do participants } \\
\text { provide spiritual } \\
\text { nursing care }\end{array}$} & \multirow[t]{3}{*}{ Promoting transcendence } & Prayer \\
\hline & & Bible scripture reading \\
\hline & & Singing spiritual songs \\
\hline & \multirow[t]{4}{*}{ Communication } & Spiritual dialogue \\
\hline & & Information \\
\hline & & Counselling \\
\hline & & Referral \\
\hline & \multirow{4}{*}{$\begin{array}{l}\text { Consequences of provision } \\
\text { of spiritual nursing care }\end{array}$} & Spiritual well-being \\
\hline & & Ability to communicate \\
\hline & & Restoration of hope \\
\hline & & Meaning and hope \\
\hline \multirow{5}{*}{$\begin{array}{l}\text { Theme 4: } \\
\text { Challenges in the } \\
\text { provision of spiritual } \\
\text { nursing care }\end{array}$} & Feeling spiritually inadequate & $\begin{array}{l}\text { Lack of education and } \\
\text { training }\end{array}$ \\
\hline & \multirow[t]{4}{*}{ To provide spiritual nursing care } & Different religious beliefs \\
\hline & & $\begin{array}{l}\text { Prefer to be prayed for } \\
\text { by a man }\end{array}$ \\
\hline & & $\begin{array}{l}\text { Contractual agreement } \\
\text { between the nurse and } \\
\text { the patient }\end{array}$ \\
\hline & & Lack of time \\
\hline
\end{tabular}

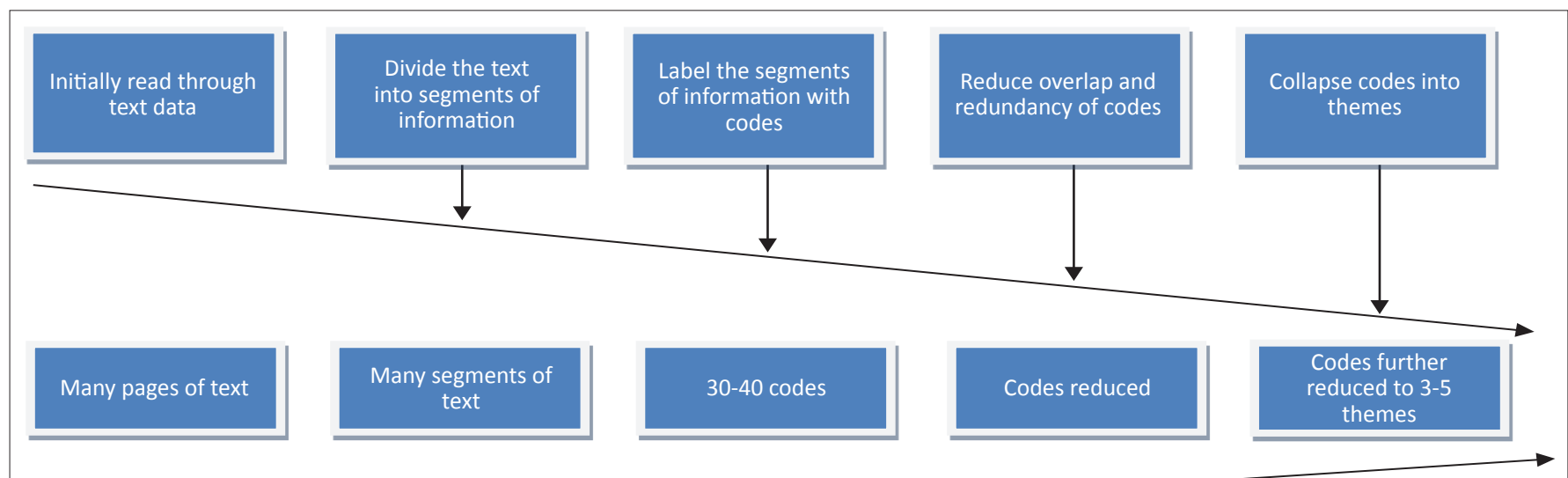

Source: (Adapted from Creswell 2003:251)

FIGURE 1: A visual model of the coding process. 
One participant suggested that relating with a patient should go beyond the status of being a patient, but as a person who is worthy of all respect, attention and consideration of the status of being a human being:

'... approaching a person as a person and not as a patient, and again allowing the communication or the relationship just to be normal. I am not a nurse or she is not a patient. We are all on the same level where we are able to communicate as human beings'. (Martha Molope, 51 year old female, professional nurse in ICU)

This expression showed the need to respect patients by how they are addressed as they enter the health care arena and are treated as equal partners in the provision of health care. This finding is supported by Rahner's (1975:1620) classic conclusion that behaviour of human beings can be understood in the context of which they are as spiritual beings. According to the SI philosophy (Blumer 1969:8), this 'self' of the patient is interpreted on the basis of the ' $\mathrm{I}$ ' who is the real person who is respected by the health care giver, as opposed to the 'me' which is a product of society or the health care environment where the patient is seen through the lens of the disease or sickness presented.

\section{Theme 2: Nurse relationships in the health care context}

The nurse-patient relationship was expressed in terms of how they interacted with patients and values that were attached to it. One participant explained that relating with a patient was understood to be spiritual when being conscious of those actions for serving or pleasing God. The patient was seen as a spiritual being to be treated so as implied in the following statement:

'I believe more in ah! doing good than in talking about faith matters with patients. I believe in works rather than words. So I live my life in my faith as I relate with my patients in such a way that I aim to please God in whatever I do or say.' (Petunia Kabongo [nee Maseko], 46 year old femaile, professional nurse in ICU)

According to this finding, the physical care provided to their patients was done in the consciousness of it being a service to God. Resorting to doing things for patients in a humane way was exemplified as a regard for people as human beings that deserves to be treated with compassion and courtesy. For more clarity on this response one participant said:

'I try to walk an extra mile for my patients, and all of them will say that, that I do my best even though they give me the most difficult patients in terms of attitude. I do my best to go the extra mile with my patients through the strength that God gives me.' (Meisi Mloto, 43 year old female, professional nurse in surgical unit)

Some participants suggested that having a positive attitude or thinking positively about patients and sacrificing for them demonstrated compassionate care to those in need of such care. Hegarty (2007:47) argues that patients deserve to be treated courteously and with compassion as they are the lifeblood of institutions. Although most of the participants had no exposure to training on spirituality, they however, recognised the value of a nurse-patient relationship embedded in spirituality as an essential aspect of patient care.
Both the individual and focus group participants seemed to have witnessed patients being treated as objects or in a dehumanising way which made them state that patients are often identified with diseases, pain, ailments or suffering as expressed by one participant:

'Bed 2 has pain or that patient with a sore throat.' (Ida Dikgole, 49 year old female, professional nurse in clinical department)

Hospitals are common ground for identifying patients by their diseases or hospital bed numbers and as such, be treated as objects. In this finding patients were seen through the lens of the disease they presented. Jeon (2004:250), based on the SI perspective explains that 'self' needs should be appreciated as being situated in interaction with others. The ' $\mathrm{I}$ ' is the part of self that is the real person created by God, and sickness or disease reduces its status to that of 'me', which depends on how others see the person. The self is never stable and is easily affected by crisis. Therefore, patients lose their self identity and assume a self that is relevant to the health context and its language.

\section{Theme 3: Provision of spiritual nursing care}

Spiritual nursing care is described by Van Leeuwen et al. (2006:881) as simply actions of assisting a patient to recognise a personal unique meaning of life in times of sickness, to strengthen that person's relationship with self, others and God and to bring an appreciation of nurse's spiritual actions or interventions in the immediate environment of care. Spiritual nursing care interventions reported by the participants indicated as promoting transcendence, communication and consequences of provision of spiritual nursing care. Prayer was cited as the most common spiritual intervention with the highest frequency of all the suggested actions employed by nurses to care for the spiritual needs of their patients. One participant articulated that practice by stating that:

'Yah ... prayer is like the first thing that I would go for because, when you're preparing a patient for surgery in a busy setting; you haven't got like the whole of other staff. Prayer is the easiest thing you can have right there to reassure a patient, and to ah ... to make them feel that even though they don't go to church or anything; God is looking out for them. So that's ... that's the first thing that ah! I would do and some of my colleagues as well.' (Petunia Kabongo [nee Maseko], 46 year old female, professional nurse in ICU)

One participant reported singing (with spiritual content) as a strategy to connect with God, to draw strength and courage in trying circumstances.

The Concise Oxford Dictionary (Seidl 1983) defines singing as 'to utter words in tuneful succession or to provide a vocal melody'. The words and lyrics can be intentionally chosen in a song to bring hope and comfort to the singers or listeners. In this instance the participants reported singing as a way of providing comfort through the words in the song and the melody thereof, as demonstrated in the following quote:

'There was nothing that could be done on that patient. Well the heart rate, blood pressure and the vital signs were very poor, and we even took some blood samples to check the blood gasses and one could see that eh ... the blood gas results were 
not compatible. The doctor decided that we throw in the towel. We had to call in the family. I suggested that we should sing and pray with them because now the patient was critical and terminally ill. So we sung a chorus and I could see the patient and relatives lighten up.' (Martha Molope, 51 year old female, professional nurse in ICU)

Participants reported that although their patients were in a medically oriented environment, conversations held with patients in times of suffering included faith in God as part of the therapy for recovery. Miner-Williams (2005:66), in support of this finding, is of the opinion that in many cases nurses do not discuss issues related to spirituality with patients. In a study conducted by Tanyi et al. (2006:535), their findings suggest that nurses should engage in spiritual dialogue by asking direct questions that are related to issues such as faith, belief in God, prayer or Bible texts. This kind of engagement was regarded as the simplest way to incorporate the patient and family's spirituality into their care, although in some instances, the patient may not be forthcoming with the information.

The symbols of prayer, reading Bible texts and singing spiritual songs were used to negotiate spiritual meaning of the situations experienced. However, they were applied indiscreetly and not as a patient centred practice.

However, patients in this study context seemed not to expect nurses to care for their spiritual needs. It confirms the conclusion that this type of care was provided by few nurses on their own and not as a generally accepted or expected aspect of professional patient care practice. Commonly spiritual needs are referred to the hospital chaplain or the patient's spiritual leaders. This finding is confirmed by Van Leeuwen et al. (2006:883) who conclude that nurses accept the provision of spiritual nursing care within the nursing profession as a co-incidence.

Participants confirmed that the reality in practice is that patients are not given the information they need. One participant empathised about the need for this interaction by stating that:

'If I were a patient and want the doctor to involve me, and after examining me telling me what is wrong with me and how he is going to treat me. A person must be informed, and must know exactly what is wrong with him or herself.' (Hellen Sebolai, 53 year old female, professional nurse in HIV / Aids clinic)

Sickness, injury and disease make patients feel vulnerable and often feel left out when discussions are made concerning their care. Participants in this study had picked up the importance to provide patients with relevant information that makes them feel important and of worth.

\section{Theme 4: Challenges in the provision of spiritual nursing care}

Most of the participants reported to be feeling inadequately prepared to render spiritual nursing care to patients. Most of the cited spiritual care provided was intuitive or done as part of their spirituality, and not necessarily as part of their professional training or responsibility. This feeling of inadequacy was experienced as a lack of education, confrontation with different beliefs of both patients and nurses, preferences of patients based on culture; need to have a contractual agreement with the patient and lack of time.

One participant in the individual interviews expressed that lack of time is one of the barriers or aspect that makes it difficult for them to deal with the patients' spiritual needs:

'... lack of time, lack of training, concern about activity outside of physician's area of expertise ... lack of interest or awareness.' (Kate Nkadimeng, 42 year old female, pediatric professional nurse)

It does seem that to provide spiritual nursing care is qualitatively different compared to other treatments given in a health care unit. Providing spiritual care is seen as something extra that needs special time to be done and not as part of the nurse's professional expertise in clinical practice. Govier (2000:35) comments that attending to someone's spiritual need is time consuming and presents a challenge to the nurse who is over stretched by under-staffing and the routine demands of busy public hospitals. Van Leeuwen et al. (2006:883) also confirm that nurses encounter varied demands and pressures in their practice.

Participants, when asked about whether they knew how to provide spiritual nursing care, indicated lack of guidelines during their basic training years on how to provide such care:

'I think also that it lies within the individual on how to carry out spiritual care. We were not guided or given the spiritual principles during training, I do not think that this is in our training curriculum.' (Kate Nkadimeng, 42 year old female, pediatric professional nurse)

One would thus assume according to the above stated finding that spiritual needs of patients are not met in clinical practice as the majority of nurses are not spiritually competent.

Although inclusion of spiritual care into the education of different health professionals is already evident, there is still a need for conceptual consensus that is coherent across all the different health professions, particularly amongst nurses. Nurses still struggle to teach and integrate spiritual nursing care to nursing practice, even though some of the literature reviewed have such content (Collins 2006:254).

The Constitution of the Republic of South Africa of 1996 (South African Government Information 2007:1) allows people to have freedom of religious affiliation. Participants seem to have understood this right and integrated spiritual nursing care from their point of view and belief particularly of the Christian faith with however a non-judgemental attitude towards the beliefs of their patients and of their colleagues.

It seemed to be more complex for the participants to render spiritual nursing care to the patients than giving professional care or attending to the needs of other dimensions of an emotional or psychosocial nature. 
TABLE 2: Trustworthiness of data.

\begin{tabular}{ll}
\hline Criteria & Strategies that were used to ensure trustworthiness \\
\hline Credibility & $\begin{array}{l}\text { Researcher credibility was enhanced by the researcher's academic qualifications and experience as a supervisor of post graduate students. Comprehensive } \\
\text { literature review was conducted through concept analysis. } \\
\text { Prolonged engagement was maintained through conducting individual and focus group interviews. Tape recordings were listened to over and over again; } \\
\text { transcripts were written and re-written, read and reread. } \\
\text { Reflexive analysis - Through this process, the researcher was able to explore feelings, experiences and own knowledge on spiritual issues that could influence } \\
\text { the findings. } \\
\text { Member checking - The draft of the analytical codes and the preliminary findings was presented to selected participants to critically judge the researcher's } \\
\text { interpretations and they concurred with some of the major findings. }\end{array}$ \\
$\begin{array}{l}\text { Involvement of information - Rich participants contributed towards transferability (Limb 2004:63). Sampling, data collection and analysis occurred until no } \\
\text { new data emerged from the interviews. }\end{array}$ \\
$\begin{array}{l}\text { Thick descriptions of the research context and methodology formed the audit trail for use by other researchers. } \\
\text { Dependability }\end{array} \quad \begin{array}{l}\text { Audit trail - A detailed research report on the exact method of data gathering, context of the interviews, data analysis and interpretation is made available. } \\
\text { Conformability }\end{array} \quad \begin{array}{l}\text { The research process undertaken was audited from the beginning to the end of the study by the study promoters and editor. The final report was submitted } \\
\text { for examination purposes with success. }\end{array}$ \\
\hline
\end{tabular}

\section{Concluding remarks}

Providing basic spiritual nursing care to patients does not need an agreement or consent, but may be necessary if offering spiritual nursing care which touches areas of belief systems, religious worldviews or doctrinal practices. Prayer and use of spiritual songs was the most common and simplest form of spiritual nursing care suggested by the participants. Participants themselves showed confidence and ability to do so without difficulty. It was, however, a challenge as patients subscribe to different belief systems or not to any which was perceived as a barrier to providing of spiritual nursing care. In spite of the constraints identified such as lack of time, the importance of providing spiritual nursing care cannot be underestimated (Ledger 2005:223).

In general, the findings suggest that the participants identified that the outcome of their spiritual intervention had a positive therapeutic effect on their patients.

\section{Ethical considerations}

Approval to proceed with the study was obtained from the Research and Ethics Committee of the Department of Health Studies at UNISA (University of South Africa). Permission to conduct the study was obtained from the Chief Medical Officer of the hospital where the study was conducted. Participation in the individual and focus group interviews was on an informed and voluntary basis. Written consent was obtained from each participant to participate and to audiotape the interviews. They had a right to refuse to participate or withdraw from the study if they felt uncomfortable without fear of victimisation. They were assured of confidentiality and privacy of information obtained during the interviews.

A spiritual counsellor was arranged to be available should any of the participants experience spiritual or psychological discomfort. Scientific integrity was ensured by appropriate acknowledgement of sources and accurate record of the references.

\section{Trustworthiness}

Scientific rigor to ensure the quality value of the final findings and conclusions in this study was measured by the use of the four criteria suggested by Lincoln and Guba (1985:290) which were credibility, transferability, dependability and conformability (Streubert-Speziale \& Carpenter 2003:133). Table 2 demonstrates how these were applied.

\section{Limitations of the study}

Although this study yielded in-depth insight into various aspects of spiritual nursing care, some people may criticise it for a lack of generalisability of its findings because of the sample size.

A limitation that may have affected the credibility of the findings was the use of the convenience sample. Participants were selected as they were available, some known to the researcher, which could have biased their responses. Some referred by those who attended the earlier focus groups which affected anonymity. All of the participants who were interviewed came from the Christian world view particularly the Protestant which might have biased the findings to be narrowly interpreted from this view only. The psychosocial processes of the phenomenon as experienced by the participants would likely look different if people of other worldviews could have been sampled. Although the shared values of practice may be experienced the same across religions, there might be other practices of spiritual nursing care that would be done differently.

\section{Recommendations}

Most of the scholarly findings that seem to may have valuable impact on clinical practice and improvement of patient care are mainly accessed by nurse scholars more than nurses on the ground that are to implement those findings at bedside care. Therefore, information and findings from this study and other nursing literature on spiritual nursing care should be made available to nurses in practice in various ways. The gap between available research findings and developed models of spiritual care and their implementation in clinical nursing practice be adressed.

In cases where nurses themselves, or their loved ones become patients, the nature of their personal experience of spiritual nursing care would have a profound effect on how they would desire that such care be provided. They should be asked to write narratives of how that care was experienced and those narratives be analysed through empirical processes. 
However, because of the small sample size in this study, the findings are not generalisable, but recommendation is made that further research be conducted with larger samples.

\section{Conclusion}

Spiritual nursing care, according to this study, was provided based on the spiritual background of the nurse, and not necessarily as part of professional preparation of the nurse during training. It was intuitive care that was provided as an in-between practice depending on the ability of the nurse to identify spiritual needs and do something about it. Prayer with or for patients and singing spiritual songs were cited as the most frequently used spiritual nursing care interventions. Spiritual nursing care is not only about prayer, reading scriptures or use of sacred music, but other modes of care such as providing patients with information or appropriate referral are examples of such care, which even non religious nurses can practice. Approach to care focuses on recognising a patient as a spiritual being worthy of genuine respect and dignity.

\section{Acknowledgements Competing interests}

The author declares that she has no financial or personal relationship(s), which may have influenced her inappropriately in writing this article.

\section{References}

Awara, M. \& Fasey, C., 2008, 'Is spirituality worth exploring in psychiatric out patients?', Journal of Mental Health 17(2), 183-191. http://dx.doi.org/10.1080/ 09638230701498390

Blumer, H., 1969, Symbolic Interactionism: Perspective and Me, Prentice-Hall, Eaglewood Cliffs.

Burnier, D., 2005, 'Making it meaningful: Post modern Public Administration and Symbolic Interactionism', Administrative Theory \& Praxis 27(3), 498-516.

Burns, N. \& Grove, S.K., 2007, Understanding nursing research, Elsevier, Philadelphia.

Callister, L.C., Bond, A.E., Matsumura, G. \& Mangum, S., 2004, 'Threading Spirituality throughout Nursing Education', Holistic Nursing Practice 18(3), 160-166. PMid:15222604

Collins, P., 2006, 'Negotiating Selves: Reflections on "unstructured interviewing"', viewed 24 June 2009, from http://www.socresonline.org.uk/socresonline/3/3/2.html

Creswell, J.W., 2003, Research design, Qualitative and Quantitative approaches, Sage, London.

De Vos, A.S., 2005, 'Qualitative data analysis and interpretation, in A.S. de Vos, H. Strydom, C.B. Fouché \& C.S.L. Delport (eds.), Research at Grass roots - For the social sciences and human service professions, Van Schaik Publishers, Pretoria.

Freshwater, D. \& Maslin-Prothero, S.E. (eds.), 2005, Blackwell's Nursing Dictionary, 2nd edn., Blackwell Publishers, Great Britain. PMCid:2870306
Govier, I., 2000, 'Spiritual care in nursing: A systematic approach', Nursing Standard 12(14), 32-36.

Hegarty, M., 2007, 'Care of the spirit that transcends, religious, ideological and philosophical boundaries', Indian Journal of palliative care 13(2), 4247. http:// dx.doi.org/10.4103/0973-1075.38898

Herman, C.P., 2007, 'The degree to which spiritual needs of patients near the end of life are met', Oncology Nursing Forum 34(1), 70-78. http://dx.doi.org/10.1188/07. ONF.70-78, PMid:17562634

Holloway, I. (ed.), 2005, Qualitative Research in Health Care, Open University Press, Berkshire, London.

Jeon, Y-H., 2004, 'The application of Grounded Theory and Symbolic Interactionsim', Scandinavian Journal of Caring Science 18, 249-256. http://dx.doi.org/10.1111/ j.1471-6712.2004.00287.x, PMid:15355518

Koslander, T. \& Arvidsson, B., 2007, 'Patients' conceptions of how the spiritual dimension is addressed in mental health care: A qualitative study', Journal of Advanced Nursing 57(6), 597-604. http://dx.doi.org/10.1111/j.1365-2648.2006.04190.x, PMid:17346318

Ledger, S.D., 2005, 'The duty of nurses to meet patients' spiritual and/or religious needs', British Journal of Nursing 14(4), 220-225. PMid:15798511

Limb, M., 2004, Grounded theory, in Qualitativ research in health care, Bassett (ed.), Whurr Publishers Ltd, London.

Lincoln, Y. \& Guba, E., 1985, Naturalistic Inquiry, Sage, Beverly Hills.

Lloyd, C. \& O'Connor, C., 2007, 'Integrating spirituality into mental health rehabilitation', International Journal of Therapy and Rehabilitation 14(4), 168-172.

McEwen, M., 2005, 'Spiritual Nursing Care State of the Art', Holistic Nursing Practice 19(4), 161-168. PMid:16006830

Meyer, C.L., 2003, 'How effectively are Nurse Educators Preparing Students to Provide Spiritual Care?', Nurse Educator 28(4), 185-190. http://dx.doi.org/10.1097/ 00006223-200307000-00010, PMid:12878898

Miner-Williams, D., 2005, 'Spirituality in nursing: Connectedness in the nurse-patient relationship', International Journal of Human Caring 9(2), 66.

Polit, D.F. \& Beck, C.T., 2008, Nursing Research-Generating and Assessing Evidence for Nursing Practice, 8th edn., Lippincott Williams \& Wilkins, Philadelphia.

Rahner, K., 1975, Encyclopedia of Theology, Burns \& Oates, London. PMid:1079556

Sawatzky, R. \& Pesut, B., 2005, 'Attributes of Spiritual Care in Nursing Practice', Journal of Holistic Nursing 23(1), 19-33. http://dx.doi.org/10.1177/0898010104272010, PMid:15665264

Seidl, J., 1983, The Concise Oxford Dictionary, Clarendon Press, Oxford.

Smith, J. \& McSherry, W., 2004, 'Spirituality and child development: A concept analysis', Journal of Advanced Nursing 3, 307-315. http://dx.doi.org/10.1046/ j.1365-2648.2003.02891.x

South African Government Information, 2007, 'Constitution of the Republic of South Africa', viewed 19 October 2008, from http://www.info.gov.za/documents, constitution/index.htm

South African Nursing Council (SANC), 2005, Rules setting out the acts or omissions in respect of which the Council may take disciplinary steps, South African Nursing Council, Pretoria.

Streubert-Speziale, H.J. \& Carpenter, D.R., 2003, Qualitative Research in Nursing Advancing the Humanistic perspective, 3rd edn., Lippincott Williams \& Wilkins, Philadelphia.

Tanyi, R.A., Recine, A.C.G., Werner, J.S. \& Sperstad, R.A., 2006, 'Perceptions of incorporating spirituality into their care: A phenomenologist study of female patients of haemodialysis', Nephrology Nursing Journal 33(5), 532-538. PMid:17044437

Taylor, E.J., 2002, Spiritual care: Nursing theory, Research and Practice, Prentice Hall, Upper Saddle River.

Tjale, A.A. \& Bruce, J., 2007, 'A concept analysis of holistic nursing care in paediatric nursing', Curationis 30(4), 45-52. http://dx.doi.org/10.4102/curationis.v30i4.1116, PMid:18402420

Van Leeuwen, R., Tiesinga, L.J., Post, D. \& Jochemsen, H., 2006, 'Spiritual care: Implications for nurses' professional responsibility', Journal of Clinical Nursing 15, 875-884. http://dx.doi.org/10.1111/j.1365-2702.2006.01615.x, PMid:16879380 